\title{
Iran-Uzbekistan Relations in the Regional Security Context
}

\author{
Guli Yuldasheva
}

\begin{abstract}
This article examines Iran-Uzbekistan relations within the regional security context, and the new efforts undertaken in 2019 to solve the security problems via bilateral and regional multinational institutions. It argues that the aggravation of the existing security situation, including geopolitical tensions in the region, contributes to the consolidation of the Iran-Uzbekistan partnership. The anti-Iran measures facilitate the process of reintegrating the region along the historical lines as part of the response to the growing global challenges. There are signs of positive regional dynamics, which can further boost Iran-Uzbekistan cooperation, and presuppose future regional connectivity among all pacified neighbors.
\end{abstract}

Keywords Iran, Uzbekistan, cooperation, geopolitical realities, security

\section{Introduction}

The process of forming a new global and regional system of international relations, started in the 1990s, has been greatly prolonged and aggravated by the never-ending geopolitical tensions, interstate conflicts and proceeding regional instability. Security and economic interests of the Central Asian states, in this context, naturally force them to become more pro-active about solving their problems without looking back at the competing global powers.

This is especially typical regarding the regional states, such as Iran and Uzbekistan. These states are located in strategically important regions of the Middle East and Central Asia, respectively. They are forecasted to play an important role in the transfer of energy in the future new geoeconomic system. Their potential roles in the ongoing Sunni-Shia conflicts are also of high importance.

The relations between the two states are facing a difficult situation as a result of such challenges and threats as geopolitical tensions, militarization of the region, growth of terrorism and drug trafficking. Moreover, they could not 
invest heavily in their weak economies nor bring about the realization of regional transport-transit projects. Both sides have apparently come to the rational conclusion that under no circumstances should the long-lasting geopolitical tensions in the region hamper their mutually beneficial partnership, as it will positively affect the regional security and economic condition.

The results and consequences of the development of these tendencies are not quite clear yet. Thus, this article aims to explore the issue by describing the two states' interests, revealing the geopolitical realities and Iranian-Uzbek responses to them, and discussing the security condition and mutual partnership in Central Asia. Doing so, the article attempts to provide a general picture of the outcomes of this regional cooperation and its great potential.

\section{Review of the Related Literature}

Iranian-Uzbek relations have been mostly studied indirectly and briefly in various studies that deal with Islam (Esposito 1992; Mohaddessin 2001; Mishku 2016) and the political development of Central Asia (Hunter 1996; Ferdinand 1994).

The role and place of Iran and the region of Central Asia in the system of regional international relations is reflected in a series of local and foreign works on geopolitics, security, and international relations. For instance, the IranianCentral Asian issue has been partly touched through revealing geopolitical interests of these states (Dugin 1999; Brzezinski 1997), or through dealing with Iranian policy in Central Asia in general (Nanay 1998; Khaidarov 1996; Wastnidge 2017; Mohsen 2016). American specialist in Middle Eastern affairs, Kenneth Katzman (2019) mainly concentrates on Iran's foreign and defense policies, and only briefly touches Iranian-Uzbek relations.

Among major works on the theme, one can mention the extensive chapter in the Vladimir Mesamed's (2010) book, devoted to Iranian policy in Central Asia. The author provides a thorough analysis of the history of Iran-Uzbekistan relations, their trade-economic, and cultural and transport partnership as well as the political dialogues conducted during the first ten years after the independence of Uzbekistan.

The issue is also examined in the author's monographs (Yuldasheva 2006, 2017) and a series of articles (Yuldasheva 2018) written on the U.S.-Iran relations within the Central Asian context. These books examine the issue through the prism of geopolitical impact of the U.S.-Iran confrontation on Central Asia, and the articles analyze new approaches and trends in the bilateral relations after 2014 and the rise to power of the new administration in Uzbekistan.

In contrast, this article, for the first time, examines Iranian-Uzbek relations within the regional security context as well as the new efforts undertaken in 2019 to solve the security problems via bilateral and regional multinational institutions. 
It covers the latest data on the bilateral contacts and international situation around Central Asia.

\section{Converging Interests}

There are objective factors for Iranian-Uzbek rapprochement: territorial, religious, cultural and linguistic closeness as well as similarity of some socio-economic problems such as unemployment and inflation.

At the end of 2018, Iran ranked 27th in the World list of the biggest economies in the world. Its GDP was worth over US\$ 454 billion (IRNA 2019b). As to Uzbekistan, in the first half of 2019, its real GDP growth increased to 5.8 percent, which is expected to increase to 6 percent in 2021(World Bank 2019). Thus, the two countries can fruitfully complement each other.

Iran has fundamental interests in the Central Asian region, and receives Uzbekistan's support in ensuring security and stability in Central Asia, which is inextricably linked with such issues as (1) addressing the current situation in Afghanistan; (2) strengthening the region's status through common geoeconomic projects; and, (3) ensuring that Iran will play the role of a "gatekeeper" in Central Asia, serving as a transit route for oil and gas pipelines and transport networks.

The Uzbek stance is exhibited in (1) the policy of Uzbekistan on securing regional good-neighborliness and formation of the stability and security belt around the region of Central Asia; (2) neutrality of Tashkent in the IranianAmerican conflict; and, (3) consolidation of ties between Iran and the leading regional actors in Central Asia-Russia, China, Turkey and India.

However, these interests face various obstacles and security challenges due to continuation of the geopolitical tension around the region. Obviously, most important among them include the continuation of the U.S.-Iran confrontation, United States-European Union disagreements, appearance of contradictory trends in the two areas adjacent to the Central Asian region (Persian Gulf and Eurasian space), aggravation of the security sphere which includes growth of regional militarization, terrorism, and drug trafficking.

\section{Geopolitical Challenges}

\section{United States-Iran Confrontation}

Confrontation between the United States and Iran forms the background of all emerging trends in the international life. U.S. Defense Secretary Mark Esper has acknowledged that the United States and some of its allies have different attitudes toward this issue. However, he has stressed that Trump is determined to stay on 
his course of "maximum pressure" through economic sanctions (Aljazeera 2019). This stimulates changes in geopolitical preferences of some states to withstand the growing challenges in political and economic life. One can mention, for instance, fluctuations of the European states between the United States and Asian states, the growing geopolitical split between the pro-U.S. and other Gulf states, and the growing cooperation of the Eurasian states, including Iran, under the aegis of China and Russia.

\section{United States-European Union (EU) Relations}

U.S. President Donald Trump's decision last year to withdraw from the Joint Comprehensive Plan of Action (JCPOA) and renew sanction policy against Iran deepened the U.S.-European long-term discrepancies. To preserve the nuclear deal, the EU leaders, Germany, France and the United Kingdom, have been attempting to salvage the JCPOA, to reduce the international tension and return to dialogue between Washington and Tehran. However, despite all official rhetoric, the European position is shaky due to its fragmented state and dependence on the United States. Almost all large European firms had to be withdrawn from the Iranian market, depressing the economy still further. Efforts made at the G7 Summit in Biarritz on August 24-26, 2019 by French President Emmanuel Macron to reconcile Iran and the United States, in fact, failed.

As a result, trade between Iran and EU member states from January to September 2019 stood at EUR€ 3.86 billion, to register a 74.92 percent plunge compared with last year's corresponding period (Financial Tribune 2019). It is clear that this situation negatively affects regional cooperation, reducing financial involvement of European companies in projects wherein Iranian participation is present. Particularly, this decreases the flow of the transport routes towards the Persian Gulf, the shortest and economically viable route for Uzbek commodities to the world markets.

\section{The Persian Gulf}

The direct response to the United States' unilateralism was the crisis of 2019. The crisis developed in the Persian Gulf, with the escalation of military tensions between Iran and the United States (e.g., incidents in May and June 2019), following the deployment of substantial military assets to the Persian Gulf by U.S. President Donald Trump. Such deployment was allegedly due to the U.S. intelligence suggesting a planned "campaign" by Iran and its allies against the U.S. forces and interests in the Persian Gulf and Iraq.

The prolonged Gulf crisis resulted in the division of the regional states into two groups: those who support the United States (Saudi Arabia and its allies) and those who are inclined to cooperate with Central Asian and other Eurasian states.

Such situation is not favorable for realization of economic projects connected with the Gulf-Chabahar project including transport corridors among Uzbekistan, 
Turkmenistan, Iran, Oman, and Katar to name just a few. This also turns China into the main investor and transit route for Central Asian commodities, resulting, for instance, in the start-up of the Tashkent-Andijan-Osh-Erkeshtam-Kashgar corridor and the China-Kazakhstan-Turkmenistan-Iran railway corridor. This one-sided foreign preference comes into collision with the Uzbekistan multivector policy which favors the diversification of transport and economy links.

\section{Eurasia}

In its turn the Gulf crisis consolidates cooperation of all Eurasian ${ }^{1}$ states, including Iran, under the aegis of China and Russia to protect themselves in economic and political spheres from the unpredicted unilateral actions by the United States. Russia and China declared the demand "to strengthen global strategic stability" and cooperate at their respective Ministry of Defense levels (Stefanovich 2019). Moreover, while traditional Gulf allies were in some confusion (Cunningham 2019) presidents of Iran, Turkey and Russia activated their cooperation. During the fifth round of the Russia-Turkey-Iran summit on Syria held in Ankara on September 17, 2019, the sides agreed steps to ease tensions in Syria's Idlib despite their lingering differences.

In their turn, Tehran and Beijing signed an agreement in their twenty-fifth year of comprehensive strategic partnership. And for the first time after the 1979 Islamic Revolution, Iran participates in a regional organization, the Free Trade Area of the Eurasian Economic Union, which it officially joined on October 27, 2019.

Additionally, Tehran is gradually strengthening its relations with the Central Asian states. It is also worth mentioning that a special envoy of Iran's Supreme Leader, Head of the Strategic Council on Foreign Relations Kamal Kharazi was in Tashkent from the end of April to the beginning of May 2019. On September 12, Iranian leaders also visited Kyrgyzstan to discuss regional security issues.

Strong opposition by Central Asian and other regional states to unilateralism in today's world politics and its negative outcomes have driven states to actively participate in the Shanghai Cooperation Organization (SCO). The SCO members are determined now to use the combined potential of regional states, international organizations, and multilateral unions to form a safe, open, and mutually beneficial and equitable space in Eurasia. The Bishkek SCO summit on June 14, 2019 acknowledged the organization as "an effective and constructive" mechanism for promoting multilateral cooperation that plays an important role in maintaining regional peace and stability. For example, the SCO member states resolutely condemn terrorism in all its forms and manifestations and urge the international community to boost global cooperation in the fight against the scourge under the United Nations' (UN) central role and through the implementation of relevant UN Security Council resolutions and the UN Global Counter-Terrorism Strategy (Presstv.com 2019). 
Security, among other considerations, led Uzbekistan to enter the Turkic Council (Gazeta.uz 2019a), which has served as an efficient mechanism for fighting against terrorism, drugs and human trafficking.

However, on the flipside, the U.S. minister of trade, Wilbur Ross, noted that entering Eurasian Economic Union (EEU) can complicate Uzbekistan's entrance to the World Trade Organization (Gazeta.uz 23 2019b). This further complicated by the fact that China, the biggest trade partner of Uzbekistan and Iran, is in real economic war with the United States.

At the same time, the U.S. sanctions reduce the scope of the regional business. For instance, the Iranian government has ambitious goals like modernizing its Chabahar port, the nominal capacity of which is intended to be increased to eighty-six million tons by 2024 (Sawhney CSIS). It is projected that via the constructed Chabahar-Zahedan railroad and Kazakhstan-Turkmenistan-Iran railway corridor, Chabahar port can be connected with the transport system of the Caspian. Realization of such an ambitious project will put India, the main Chabahar sponsor, and Iran in the epicenter of the ongoing geo-economic processes in the Middle East, Central, and South Asia. In other words, the project is gaining momentum, and will eventually turn into one of the largest trade routes in the world.

In this context, the United States seems to have chosen a cautious regional stand, not hampering too much to the Chabahar project and leaving the door open to potential U.S. involvement into regional projects in future. This can be explained by the growing Chinese regional power and in contrast to it, U.S. intentions to preserve its partnership with India, the main U.S. South Asian ally and a potential conductor of U.S. strategy in Central Asia via the still not forgotten American New Silk Road initiatives.

Hence, there is a real geopolitical struggle ongoing in and around Central Asia that deepens the instability of international relations and incites counteractions in the political and economic spheres that seriously hampers productive regional cooperation.

\section{Security Situation}

Geopolitical tensions resulted in various challenges and threats to the regional cooperation. Particularly, Iran's withdrawal from the JCPOA and two phases of Iran's reduction of its nuclear commitments as well as Tehran's declarations on possibility of further reducing Iran's obligations within the JCPOA's framework have significantly increased potential for nuclear race and military conflicts in the world. Iran has taken these measures in response to the unilateral U.S. policy and Europe's lack of efficient actions against the U.S. sanctions.

The regions and powers, neighboring or having stakes in Central Asia, 
have been strengthening their military power. According to the Stockholm International Peace Research Institute (SIPRI), in 2018, military expenditures of all twenty-nine members of the North Atlantic Treaty Organization has been US\$ 963 billion or 53 percent of all world expenditures. Since 2010, the United States' military spending increased 4.6 percent (SIPRI 2019), and in 2019 it amounted already US\$ 725.5 billion (Zarubejnoe voennoe obozrenie 2019). China's military spending is second increasing by 5 percent to US $\$ 250$ billion in 2018, and Russian expenses were US\$ 61.4 billion. Six out of the ten countries which had the biggest share of the military expenditures in their GDP in 2018 were from the Middle East (SIPRI 2019).

Simultaneously, the disbalance of interests among the main international actors and the concentration of their attention on solving their discrepancies led to the growth of terroristic acts in proximity to Central Asia, e.g. activation of such radical formations as Taliban, Haqqani Network, Da'esh as well as Al Qaeda and its proscribed affiliates. According to the Global Terroristic Index assessments, the states with the highest indexes of terrorism are Afghanistan (9.603), Iraq (9.241), Syria (8.006), and Pakistan (7.889) (Global Terrorism Index 2019). According to the UN report, from 2,500 to 4,000 representatives of the Islamic State movement operate in Afghanistan (Central.asia-news 2019).

Terrorism, in its turn, is known to be financially supported through drug trafficking. Uzbekistan is a northern transit route of opiates and heroin from Afghanistan to Russia and Europe. This trend is becoming increasingly permanent due to the prolonged clash of interstate interests and use of clandestine activities and unofficial tools by some actors to protect their own interests. In 2018 alone, 263,000 hectares were sowed with opium poppies in Afghanistan. The recent seizure and burning of more than one tons of drugs in Uzbekistan could be one of the outcomes of this condition (Bashlayev 2019).

This unpredictable and complex situation diverts attention from peaceful projects and instead focuses forces, energy, and resources to reducing these security challenges and threats.

\section{Iranian-Uzbek Partnership}

Paradoxically, the anti-Iranian measures only renewed mutual interest and contributed to the process of reintegrating the region along the historical lines as part of the response to the growing global challenges. Thus, Iran and Uzbekistan are looking for efficient ways to restore and strengthen their lost links bilaterally and within the regional networks.

In particular, a special envoy of Iran's Supreme Leader and Head of the Strategic Council on Foreign Relations, Kamal Kharazi, was in Tashkent from the end of April to the beginning of May 2019. The parties discussed bilateral 
and regional issues, focusing on the construction of the Mazar-i-Sharif-Herat railway and the implementation of the Uzbekistan-Turkmenistan-Iran-Oman transport corridor agreement. The sides want to increase the number of the container shipments along this route. Tehran considers Uzbekistan to be the most strategically important and shortest transit, connecting the region to China and other Eastern Asian states. And, vice versa, Tashkent considers Iranian routes the shortest and most economically viable ones to the world markets.

To promote such relations, Uzbekistan's President Shavkat Mirziyoyev, speaking at the SCO summit in Bishkek on June 14, 2019, called for the development of the SCO Cooperation Strategy for the development of interconnectedness for efficient economic and transport corridors (Podrobno.uz 2019a). Correspondingly, on July 3 , 2019, the Uzbek governmental delegation headed by the Prime-Minister Abdulla Aripov visited Mazari-Sharif (Ministry of Foreign Affairs of the Republic of Uzbekistan 2019) with the aim of invigorating Uzbek-Afghan trade relations.

Concurrently, Tehran, inclined to develop strong partnership among Muslim states, strives to promote more active partnership with Uzbekistan within the Organization of Islamic Conference (OIC). It is expected, for instance, that Iranian side will participate in the second summit of the OIC on science and technology in 2020 in Tashkent. To strengthen this potential partnership, Tehran suggests the restoration of Islamic civilization center in the territory of Uzbekistan.

Uzbekistan is against any military conflicts in the close regional neighborhood and supports Russian and Indian's stance on Iran. In the interests of its economic and social security Tashkent is interested in promoting the realization of such existing projects, like Chabahar, with Iran. The sanction policy around the region has negatively affected and slowed reforms, reducing the flow of investments into the country. This is especially troubling now that Tashkent is trying to further consolidate economic partnership with all major powers, regional states, and international institutions and relies greatly on regional peace, support, and financial-technical assistance.

In these circumstances, to peacefully solve the emerging tense situation around Iran, Tashkent also supports the idea of creating joint commission on JCPOA. At the same time Tashkent is ready to use INSTEX ${ }^{2}$ financial mechanism in cooperating with Iran. However, in order to initiate such cooperation, Tehran would first need to fulfill its obligations on the nuclear program.

\section{Positive Outcomes of Regional Cooperation}

In response to the sanction policy, Iran is active in various regional initiatives, like EEU, Astana summit among Iran, Turkey, and Russia; summit among Iran, Azerbaijan, and Russia; as well as, among Iran, India, and Afghanistan. Achieving mutual understanding, consensus, and some level of partnership on the burning 
regional issues naturally contributes to peace and stability around Uzbekistan and creates favorable circumstances to deepen further bilateral Uzbekistan-Iran relations and within the regional organizations.

To judge the efficiency of the undertaken regional efforts let's turn to their immediate outcomes. During the last years, Iran has proved its peaceful oriented policy by absence of propaganda or terroristic acts and by its recent peacekeeping operations in Syria. To reduce the regional tension, Tehran continues to keep a patience stance and, in favor of stability, tries to find common language with regional powers. Thus, Iran's President, Dr. Rouhani admits:

Iran, Turkey and Russia have been able to take good steps in establishing peace and security and fighting terrorism in Syria... The three countries' agreement prevented bloodshed in Idlib from breaking out and we hope that the Astana process, along with Geneva process, can achieve full success (Mehr News 2018).

Other Gulf states are also increasingly predisposed to deepen their cooperation with historically, religiously, and culturally close Central Asian states. Some Gulf states are too pragmatically minded to reject Iran from the regional cooperation. Therefore, it is not surprising that Qatar, Oman, and Arab Emirates are starting economic projects with Central Asian states, participated by Iran, and are obviously interested in realization of Chabahar project and its offshoots such as future North-South corridors able to join their states with other Eurasian states (Mehr News 2019).

On the whole, seventeen countries expressed their willingness to contribute to the development of Chabahar project in the south of Iran. Uzbekistan has repeatedly announced its economic interest in this project, and its potential trans-Afghan offshoots to gain access to the Gulf and further to the Asian and European markets.

Moreover, India, the main Chabahar's investor, proposed to double trade with Iran in the next five years from the current level of US\$ 13.8 billion, and Indian Trade between India and Iran increased to US $\$ 13.8$ billion over 2017 and 2018 from US\$ 12.9 billion in the previous fiscal (Iranreview 2018).

Simultaneously, Iran and Azerbaijan signed very important agreements on the Caspian area and started cooperation in the field of oil and gas exploration and transit, as well as Astara-Astara railroad line (Iran.ru 2019). Trade exchanges between both states achieved 70 percent increase, grounds are prepared now to promote mutual cooperation in the fields of auto-making and industry and boost sea collaboration with Azerbaijan (IRNA 2019f).

The leading regional power, China, which is the first trade partner of Uzbekistan with US\$3895.5 million of trade turnover from January to June 2019 (State Committee 2019) and the main Iranian economic partner, invested in Iranian energy sphere about US\$280 billion and, hence, consolidated its stand in 
the Gulf, simultaneously releasing Iranians from the economic dependency on the West (Detaly 2019).

One of the new trends is the growth of regional security cooperation within the Shanghai Cooperation Organization (SCO). Iran, having now the status of an observer in this organization, has all rights and prerequisites to become a member-state in the future. Owing to realization of the renewed SCO antinarcotic strategy, more than 40 percent of the drugs substances were seized in the territory of Eurasia during the last five years. In 2018, alone, the SCO states put an end to 360 terroristic crimes, liquidated approximately 70 militants, and reduced the access to more than 160 thousand sites, including those which have a terroristic and extremist character (Podrobno.uz 2019b).

In this sense inclusion of India and Pakistan into the SCO ranks has significantly increased its potential in counteracting present challenges and threats. Now SCO joins nearly half of the world population. It is worth mentioning that since May 23, 2004, Tashkent has hosted the SCO Regional Anti-Terroristic Center, and since January 2019, the Former Director of the Institute of Strategic Studies of Uzbekistan, Vladimir Norov, is the Secretary-General of the SCO.

So, we can observe positive dynamics of the regional cooperation that will certainly contribute to further consolidation of the Iran-Uzbekistan ties, as they are evolving within these regional formations and various unions of economic and security partners. This is already contributing to the process of establishing regional peace and stability, and achieving better mutual understanding which are necessary for developing bilateral partnership.

\section{Positive Opportunities for the Future}

There are some other positive tendencies observed, which can further strengthen these mentioned achievements, and boost Iran-Uzbekistan cooperation. Some signals from Washington can indicate its intentions to attempt to pacify and reconcile the whole region of the Middle East, Central and South Asia in future.

First, the United States has not fully ceased cooperation on security issues with all regional actors, including its main adversaries, i.e. Russia and China, as well as, all Central Asian states, including Uzbekistan, a close partner of the United States on Afghanistan. It periodically negotiates with each of these and other states to come to a consensus over current issues in the region. Apparent American pragmatism and rational thinking on security issues can lead to some stability and peace in the region, indicating Washington's unwillingness to object strongly to Uzbekistan-Iran cooperation. Even the United States is forced to acknowledge the existing regional realities.

Second, the trend for regional stability can also be seen in evolution of the U.S.-Uzbekistan relations. Washington activates its policy regarding the 
strategically located Uzbekistan. Its assistance to this key Central Asian state grew to approximately US\$28.1 million in fiscal year 2018, from US\$ 10.1 million in fiscal year 2016 (U.S. Embassy in Uzbekistan 2019).

Third, to provide the United States with a positive image and fulfill the regional promises on reconstruction and development of Afghanistan, the U.S. State Department issued a waiver for Iran-India project on Chabahar. It seems that these tendencies not only contradict the policy of the regional war due to the closeness of Iran to Central Asia, but also presuppose regional connectivity among all pacified neighbors in the future.

Simultaneously, the European Union approved on June 17, 2019 the new EU Strategy for Central Asia under the sub-heading "New Opportunities for a Stronger Partnership," that not only fully complies with the priorities of Uzbekistan Development Strategy for 2017-2021, but apparently includes Iran in their regional plans. The three European signatories to the Iranian nuclear deal reiterated their commitment to the JCPOA's implementation, saying that they will keep looking for solutions to stop the deal from unravelling and they will continue active engagement with all interested parties, in the interest of the preservation of international peace and security (IRNA 2019d).

Meanwhile, Iran proposed a new initiative called the "Ormuz peaceful initiative" to provide, among other things, security of energy and free oil transportation via Ormuz strait (Tehran Times 2019b). Moscow, in its own way, is preparing security doctrine for the Persian Gulf based on the international agreements till the end of 2019 (Tehran Times 2019a).

Pakistan intends to expand trade ties with Iran (IRNA 2019a) and complete the gas pipeline from Iran despite major hurdle created by the U.S. sanctions on Iran-Pakistan banking ties; Iran in its own side wants to settle its differences with Saudi Arabia with assistance of Islamabad. Pakistani Prime Minister Imran Khan has recently met with both Iranian and Saudi officials in a bid to find a middle ground to bring the two regional powers to the negotiating table (IRNA 2019e).

\section{Conclusion}

Thus, the situation is very complicated, but not necessarily prone to a new military conflict. It is clear that neither the United States nor Iran is interested in war-they have too many economic and political stakes in the vast region of the Middle East and Central and South Asia. It seems, pragmatic U.S. President Trump simply wants Tehran to initiate new negotiations on the terms acceptable for the United States and its new tactic of "great power competition" in the Middle East and South Asia.

Meanwhile, Uzbekistan proceeds with the realization of the vitally important transport-transit and energy projects that shows that it is not inclined to fully 
observe the United States' instructions on Iran, risking the detriment of its own economy and security interests. In fact, American business interests also demand the construction of the regional transport network. They also seek stability and peace as well as positive capital flow in the region.

It is also clear that Iran's incremental withdrawals from the JCPOA are a calculated response to the unprecedented sanctions pressure, allowing Iran to resolutely reciprocate, while creating some leverage for potential future negotiations. Iran's government is betting that it can withstand a weakened economy and the increasing likelihood of a military conflict, but that depends on whether the European Union, Russia, and China can offer economic and security lifelines or not.

It is obvious that there is no way to avoid or at least to restrain the existing regional problems and achieve the projected results except to enter into dialogue and organize mutually beneficial economic cooperation. In this sense, Tashkent supports Iran's stance on the development of collective regional security and talks.

Through such talks, Iran and Uzbekistan would be able to participate in bilateral and multilateral negotiations to reduce geopolitical tensions with the United States, Israel, Saudi Arabia, and others. They could arrange fruitful cooperation based on their common interest. For instance, they would be able to initiate cooperation in their transport and transit projects. It is expedient within this framework to proceed with completing the Chabahar project in the territory of Afghanistan (routes to Mazari-Sharif-Gerat), the North-South corridor, the Uzbekistan-Turkmenistan-Iran-Oman transport corridor, as well as the ChinaTajikistan-Uzbekistan highway bound for Turkmenistan and Iran.

Additionally, both states would receive the opportunity to cooperate multilaterally in the schemes of possibly attracting Iran to the recently initiated "road map" of the actions of the SCO-Afghanistan Contact Group in the security sphere.

Today much depends on how efficiently Iran and Uzbekistan can respond to the existing geopolitical and economic risks-the key geopolitical risk is still the U.S. economic sanctions against Iran.

\section{Notes}

1. "Eurasian" here means on the Eurasian continent.

2. INSTEX stands for the Instrument in Support of Trade Exchanges, a European special-purpose vehicle, established in January 2019, to facilitate non-USD transactions to avoid breaking U.S. sanctions. 


\section{References}

Aljazeera. 2019. "US Defence Chief: Iran 'Inching' Towards Talks.” September 6. https:// www.aljazeera.com/news/2019/09/defence-chief-iran-inching-talks-190906105745558. html (accessed September 6, 2019).

Bashlayev, Konstantin. 2019. "V Tashkente sojgli svyshe tonny narkotikov" [Over a Ton of Drugs Burned in Tashkent]. Pravda Vostoka, June 26. https://pv.uz/ru/news/svyshetonny-narkotikov (accessed June 28, 2019).

Brzezinski, Zbigniew. 1997. The Grand Chessboard: American Primacy and its Geostrategic Imperatives. New York: Basic Books.

Caravanserai. 2019. "Ugroza "Islamskogo gosudarstva" zamayachila v Afghanistane" [The Threat of an "Islamic State" Looms in Afghanistan]. June 14. https://central.asia-news. com/ru/articles/cnmi_ca/features/2019/06/14/feature-01 (accessed June 15, 2019).

Cunningham, E. 2019. "Allies in the Persian Gulf Pushed the U.S. to Confront Iran: Now They're Not Sure What They Want." Washington Post, July 10. https://www. washingtonpost.com/world/middle_east/allies-in-the-persian-gulf-pushed-the-usto-confront-iran-now-theyre-not-sure-what-they-want/2019/07/09/89f44ad4-976711e9-9a16-dc551ea5a43b_story.html (accessed September 10, 2019).

Detaly. 2019. "Neft v obmen na voiny: Iran i Kitai podpisali strategicheskoe soglashenie" [Oil in Exchange for War: Iran and China Sign Strategic Agreement]. September 6. https://detaly.co.il/neft-v-obmen-na-vojnu-iran-i-kitaj-podpisali-strategicheskoesogl ashenie/?fbclid=IwAR2crKwVYcBQFhS1doNWnKV2nzjPgAPnl9Wa7XtxXpxnvWn mXFJWtDJtH1Y (accessed September 10, 2019).

Dugin, Aleksandr. 1999. Osnovi geopolitiki [Fundamentals of Geopolitics]. Moscow: Arktogeya-tsentr.

Esposito, John L. 1992. The Islamic Threat: Myth or Reality. New York: Oxford University Press.

Fact Military. 2019. "Voenno-strategicheskie realii mejdunarodnoi obstanovki: vizovi i ugrozi bezopasnosti Rossii" [Military-Strategic Realities of the International Situation: Challenges and Threats to Russia's Security]. http://factmil.com/publ/obshhee/analiz/ voenno_strategicheskie_realii_mezhdunarodnoj_obstanovki_vyzovy_i_ugrozy_ bezopasnosti_rossii_2019/71-1-0-1578 (accessed October 20, 2019).

Ferdinand, Peter, ed. 1994. The New Central Asia and Its Neighbors. London: The Royal Institute of International Affairs/Pinter Publishers.

Financial Tribune. 2019. "Iran-EU Trade Plunges 74\%." November 16. https:// financialtribune.com/articles/domestic-economy/100769/iran-eu-trade-plunges-74 (accessed December 12, 2019).

Gazeta.uz. 2019a. "Prioriteti Uzbekistana v sotrudnichestve s Turkskim sovetom" [Priorities of Uzbekistan in Cooperation with the Turkic Council]. October 16. https://www. gazeta.uz/ru/2019/10/16/priority (accessed October 17, 2019).

Gazeta.uz. 2019b. "Stremlenie k EAES mojet uslojnit vstuplenie v VTO - ministr torgovli SSHA" [The Desire for the EAEU may Complicate the Entry into the WTO - US Secretary of Commerce]. October 23. https://www.gazeta.uz/ru/2019/10/23/us-uz/ (accessed October 24, 2019).

Hunter, Shireen T. 1996. Central Asia since Independence. Westport, CT: Praeger.

Institute for Economics \& Peace. 2019. Global Terrorism Index 2019: Measuring the Impact 
of Terrorism. Sydney: Institute for Economics \& Peace. http://visionofhumanity.org/ reports (accessed December 12, 2019).

Iranreview. 2018. "India Proposes to Double Transactions with Iran." September 15. http:// www.iranreview.org/content/Documents/India-Proposes-to-Double-TransactionsWith-Iran.htm (accessed September 16, 2018).

Iran.ru. 2019. "President Irana Rohani: Iran ne'uyazvim pered zagovorami, davleniem I sanktsiyami" [Iranian President Rouhani: Iran is not Vulnerable to Conspiracies, Pressure and Sanctions]. October 25. https://www.iran.ru/news/politics/114246/ Prezident_Irana_Rouhani_Iran_neuyazvim_pered_zagovorami_davleniem_i_ sankciyami (accessed October 25, 2019).

IRNA. 2019a. "Pakistan Intends to Expand Trade Ties with Iran Despite US Sanctions." July 4. https://en.irna.ir/news/83380943/Pakistan-intends-to-expand-trade-ties-withIran-despite-US-sanctions (accessed July 20, 2019).

IRNA. 2019b. "Iran Tops in World Bank Biggest Economies." July 12. https://en.irna.ir/ news/83392572/Iran-tops-in-World-Bank-biggest-economies (accessed July 15, 2019).

IRNA. 2019c. “Oman Ready to Invest in Chabahar Plans.” July 12. https://en.irna.ir/ news/83392466/Oman-ready-to-invest-in-Chabahar-plans (accessed July 15, 2019).

IRNA. 2019d. "Europe Reafirms Support for Iran Nuclear Deal, will Look for Further Solutions." July 14. https://en.irna.ir/news/83395863/Europe-reafirms-support-forIran-nuclear-deal-will-look-for (accessed September 10, 2019).

IRNA. 2019e. "Pakistani PM Khan to Continue Mediation between Saudi Arabia." October 24. https://en.irna.ir/news/83529890/Pakistani-PM-Khan-to-continue-mediationbetween-Saudi-Arabia (accessed October 24, 2019).

IRNA. 2019f. "President Rouhani: Iran-Azerbaijan Ties Enhances to Satisfactory Levels." October 24. https://en.irna.ir/news/83530076/President-Rouhani-Iran-Azerbaijanties-enhances-to-satisfactory (accessed October 25, 2019).

Katzman, Kenn. 2019. “Iran's Foreign and Defense Policies." Congressional Research Service. July 23. https://crsreports.congress.gov (accessed September 10, 2019).

Khaidarov, Abdusamat. 1996. "Tsentralnaya Aziya vo vneshnei politike Islamskoi Respubliki Iran" [Central Asia in the Foreign Policy of the Islamic Republic of Iran]. Ph.D. diss. Tashkent State Institute of Oriental Studies.

Mehr News. 2018. "Iran Determined to Cooperate with UN in all Fields." September 27. https://en.mehrnews.com/news/138116/Iran-determined-to-cooperate-with-UN-inall-fields (accessed September 30, 2018).

Mehr News. 2019. “Qatar Opposes to US Unilateral Sanctions against Iran.” May 2. https:// en.mehrnews.com/news/.../Qatar-opposes-to-US-unilateral-sanctions-against-Iran (accessed May 15, 2019).

Mesamed, Vladimir. 2010. Iran v Tsentralnoi Aziyi: dva desyatiletia dialoga [Iran in Central Asia: Two Decades of Dialogue]. Moscow: Institut Blijnego Vostoka. book.iimes.su/ wp-content/uploads/main/irn2010.pdf (accessed February 13, 2018).

Ministry of Foreign Affairs of the Republic of Uzbekistan. 2019. "SMI Afganistana o vizite pravitelstvennoi delegatsii v g. Mazari-Sharif" [Afghanistan Mass Media on the Governmental Delegation Visit to Mazar-i-Sharif]. July 3. https://mfa.uz/ru/press/ smi/2019/07/19840 (accessed February 9, 2020).

Mishku, B. Mishel. 2016. "Uzbekistan and the Muslim Middle East." Journal of South Asian 
and Middle Eastern Studies 39 (2): 63-81.

Mohaddessin, Mohammad. 2001. Islamic Fundamentalism: The New Global Threat. Washington, DC: Seven Locks Press.

Mohsen, Milani. 2016. Iran in a Reconnecting Eurasia: Foreign Economic and Security Interests. Washington, DC: Center for Strategic and International Studies (CSIS)/ Rowman \& Littlefield. https://www.csis.org/analysis/iran-reconnecting-eurasia (accessed November 14, 2016).

Nanay, Julia. 1998. “Iran’s Role in Central Asia. A Dialogue with AIPAC.” Washington, DC: The Petroleum Finance Company.

Podrobno.uz. 2019a. "Ekonomicheskiy forum v Samarkande, novie stolitsi i zelenyi poyas: shest initsiativ Mirziyoeva na sammite SHOS v Bishkeke" [Economic Forum in Samarkand, New Capitals and the Green Belt: Six Initiatives of Mirziyoyev at the SCO Summit in Bishkek]. June 14. https://www.podrobno.uz/cat/politic/ekonomicheskiyforum-v-samarkande (accessed June 20, 2019).

Podrobno.uz. 2019b. "V stranah SSHOS v 2018 godu presekli 360 terroristicheskih prestuplenii, likvidirovali pochti 70 boevikov - gensek Vladimir Norov" [In 2018, in the SCO Countries, 360 Terrorist Crimes were Stopped, almost 70 Militants were Eliminated - Secretary General Vladimir Norov]. September 26. https://www. podrobno.uz/cat/politic/v-stranakh-shos-v-2018-godu-presekli-360 (accessed September 28, 2019).

Presstv.com. 2019. "SCO Plays Constructive Role in Promoting Regional Peace, Stability: Statement." June 14. https://www.presstv.com/Detail/2019/06/14/598503/SCOBishkek-security (accessed July 12, 2019).

Sawhney, Asha. "Chabahar Port: Unlocking Afghanistan's Potential." Washington, DC: Center for Strategic and International Studies (CSIS). https://www.csis.org/chabaharport-unlocking-afghanistans-potential (accessed August 9, 2019).

State Committee of the Republic of Uzbekistan on Statistics. 2019. Socio-Economic Situation of the Republic of Uzbekistan, January-June 2019. https://stat.uz/uploads/ doklad/2019/yanvar-iyun/ru/yanvar-iyun_2019(rus).pdfSTATE (accessed July 20, 2019).

Stefanovich, Dmitriy. 2019. “Tsentr-2019: Chto stoyit za manevrami Rossiyi i Kitaya v Tsentralnoi Azii" [Center 2019: What is Behind the Maneuvers of Russia and China in Central Asia]. Eurasia Expert. September 16. https://eurasia.expert/chto-stoit-zamanevrami-rossii-i-kitaya-v-tsentralnoy-azii (accessed September 17, 2019).

Stockholm International Peace Research Institute (SIPRI). 2019. "World Military Expenditure Grows to \$1.8 Trillion in 2018." April 29. https://www.sipri.org/media/ press-release/2019/world-military-expenditure-grows-18-trillion-2018 (accessed May 05, 2019).

Tehran Times. 2019a. "Russia to Present Own Persian Gulf Security Doctrine till Yearend." October 23. https://www.tehrantimes.com/news/441461/Russia-to-present-ownPersian-Gulf-security-doctrine-till-yearend (accessed December 12, 2019).

Tehran Times. 2019b. "Hormuz Peace Initiative a Step Forward in Reducing Regional Tension: Araghchi.” December 6. https://www.tehrantimes.com/news/442715/ Hormuz-peace-initiative-a-step-forward-in-reducing-regional-tension (accessed December 12, 2019).

U.S. Embassy in Uzbekistan. 2019. U.S.-Uzbek Annual Bilateral Consultations: A New Era 
of Strategic Partnership. February 26. https://uz.usembassy.gov/u-s-uzbek-annualbilateral-consultations-a-new-era-of-strategic-partnership (accessed February 27, 2019).

Wastnidge, Edward. 2017. "Central Asia in the Iranian Geopolitical Imagination." Cambridge Journal of Eurasian Studies 1. https://doi.org/10.22261/1YRJ04 (accessed January 12, 2018).

World Bank. 2019. Uzbekistan: Recent Developments. http://pubdocs.worldbank.org/ en/197351492011115514/mpo-uzb.pdf (accessed December 10, 2019).

Yuldasheva, Guli. 2006. Irano-amerikanskie otnosheniya na sovremennom etape i ih vozdeistvie na geopoliticheskuyu situatsiyu v Tsentralnoi Aziyi [Iran-US Relations at the Present Stage and their Impact on the Geopolitical Situation in Central Asia]. Tashkent: Fan.

Yuldasheva, Guli. 2017. The Role of Iran and the United States of America in Geopolitics of Central Asia. Riga: Latvian Institute of International Affairs. http://liia.lv/en/ publications/the-role-of-iran-and-the-united-states-of-america-in-geopolitics-ofcentral-asia-619 (accessed January 02, 2018).

Yuldasheva, Guli. 2018. "Iran and Central Asia: Peculiarities and Perspectives." Uzbekistan's Contemporary History Issues (2): 38-50.

Guli Ismatullaevna Yuldasheva (Ph.D.) is a Senior Scientific Fellow at the CoordinationMethodological Center on the Contemporary History issues under the Academy of Sciences of the Republic of Uzbekistan, Tashkent, Uzbekistan. Her sphere of scientific interests includes international relations, geopolitics in Central Asia, political Islam, social exclusion/inclusion, gender issues, labor migration and modern history of Uzbekistan. She has published a series of articles relating to these research interests in Central Asia and the Caucasus, Caucasian Review of International Affairs, SSHA I Kanada (United States and Canada), Ijtimoyii fanlar Ozbekistonda [Social Sciences in Uzbekistan], and Sharqshunoslik [Oriental Studies].E-mail: guli.yuldasheva@fulbrightmail.org, guli_57@mail.ru. 